\title{
PERBANDINGAN SLAB DENGAN DROP PANEL DAN SLAB DENGAN BALOK DITINJAU DARI VOLUME BETON DAN BIAYA
}

\author{
Handaya $^{1}$ dan Arianti Sutandi ${ }^{2}$ \\ ${ }^{1}$ Program Studi Sarjana Teknik Sipil, Universitas Tarumanagara, Jl. Letjen S. Parman No.1 Jakarta \\ Email: handaya31.ruslim@gmail.com \\ ${ }^{2}$ Program Studi Sarjana Teknik Sipil, Universitas Tarumanagara, Jl. Letjen S. Parman No.1 Jakarta \\ Email: ari.sutandi@gmail.com
}

\begin{abstract}
ABSTRAK
Pembangunan gedung bertingkat yang terjadi dihampir seluruh kota di Indonesia, berdampak pada peningkatan kebutuhan material konstruksi. Salah satu penggunaan material konstruksi yang paling banyak dibutuhkan adalah beton. Penggunaan material beton pada bangunan tinggi salah satunya ada di elemen struktur slab atau pelat lantai. Ada dua teknik dalam sistem konstruksi slab yaitu slab dengan drop panel dan slab dengan balok. Slab dengan Drop panel merupakan jenis pelat dua arah tanpa balok yang langsung menumpu pada kolom dan pada daerah sambungan slab dengan kolom diberi perkuatan berupa drop panel. Slab dengan drop panel memiliki kelebihan dalam mengurangi ketinggian struktur dan mempersingkat waktu pengerjaan konstruksi, adapun kekurangannya adalah flat slab membutuhkan pelat yang lebih tebal dari pelat konvensional biasa, untuk mengatasi lendutan dan punching shear. Dalam penelitian ini, suatu struktur beton bertulang basement parkir 7 lantai akan ditinjau volume penggunaan material betonnya dengan 2 pembanding, yaitu slab dengan drop panel dan slab dengan balok. Dalam perhitungan digunakan peraturan SNI 03-2847-2013 dan ACI 318-05 untuk menentukan dimensi pelat lantai dan balok. Hasil penelitian menunjukkan volume penggunaan material beton pada tipe slab dengan drop panel sebesar $31268.55952 \mathrm{~m}^{3}$ sementara tipe slab dengan balok sebesar $29244.93 \mathrm{~m}^{3}$. Dan selisih biaya dari kedua tipe pelat tersebut sebesar Rp. 1.902.211.749,-
\end{abstract}

Kata kunci: Flat Slab, Drop Panel, Konvensional, Balok, dan Beton

\section{PENDAHULUAN}

\section{Latar belakang}

Dalam kurun waktu beberapa tahun terakhir, tingkat pembangunan di Indonesia mengalami peningkatan yang sangat cepat, Indonesia juga menjadi pasar konstruksi terbesar di asia tenggara. Pada tahun 2018 pasar konstruksi Indonesia diproyeksikan mencapai 451 triliun rupiah (Detik.com, 2018). Hal ini sejalan dengan memasukinya masa pembangunan untuk sarana dan prasarana di Indonesia. Ditandai dengan pembangunan gedung- gedung baru di kota besar maupun di daerah, Indonesia saat ini sedang berada dalam fase pemerataan proses pembangunan di seluruh wilayah Nusantara. Dengan adanya pembangunan yang besar, maka akan berpengaruh terhadap kebutuhan material konstruksi yang juga meningkat. Salah satu material yang paling utama adalah penggunaan material beton pada pekerjaan struktur. Dimana sebagai contohnya adalah penggunaan material beton pada pekerjaan $s l a b$ atau pelat lantai. Pekerjaan $s l a b$ atau pelat lantai merupakan salah satu pekerjaan struktural yang sangat penting dalam proses konstruksi. Alasan dipilihnya pekerjaan $s l a b$ atau pelat lantai sebagai bahan studi, karena pekerjaan slab atau pelat lantai sangat berpengaruh terhadap konstruksi bangunan, yaitu dalam aspek kekuatan dan kekakuan suatu bangunan. Beberapa studi kasus menyatakan keruntuhan suatu bangunan terjadi akibat adanya kesalahan dalam mendesain pelat lantai. Dalam pekerjaan slab atau pelat lantai, terdapat beberapa tipe pelat lantai yang banyak digunakan pada konstruksi. Namun yang akan dibahas pada studi kali ini adalah pelat lantai tipe slab dengan drop panel dengan pembanding slab dengan balok.

Dari penjelasan diatas akan dilakukan penelitian mengenai dua jenis pelat lantai, slab dengan drop panel dan slab dengan balok. Dimana dalam penelitian akan ditinjau manakah yang lebih baik antara kedua metode tersebut, jika dibandingkan dari segi volume penggunaan material beton dan biaya. 


\section{TINJAUAN PUSTAKA}

\section{Pelat lantai}

Pelat lantai atau slab adalah sebuah elemen struktur horizontal yang berfungsi menyalurkan beban mati maupun beban hidup menuju rangka pendukung vertikal dari suatu sistem struktur. Elemen- elemen horizontal tersebut dapat dibuat bekerja dalam satu arah ataupun bekerja dua arah yang saling tegak lurus (biaksial).

\section{Tipe- tipe sistem konstruksi pelat lantai}

Beberapa tipe pelat lantai yang banyak digunakan pada konstruksi diantaranya :
a. Sistem Lantai Flat Slab
b. Sistem Lantai Grid (Waffle System)
c. Sistem Pelat dan Balok
d. Untuk menempatkan kabel listrik dan lampu pada ruang bawah
e. Meredam suara dari ruang atas maupun dari ruang bawah
f. Menambah kekakuan bangunan pada arah horizontal

\section{Drop panel}

Drop panel adalah struktur tambahan yang digunakan pada pelat lantai sistem flat slab. Drop panel pada sistem flat slab ini sebenarnya bertugas sebagai pengganti balok, Penggunaan drop panel bertujuan untuk menahan gaya geser dan mengurangi keruntuhan pons yang terjadi pada daerah sambungan pelat dan kolom.

Drop panel juga dapat dikatakan sebagai penebalan pada kepala kolom, yang berfungsi untuk mendistribusikan langsung semua beban pada pelat lantai ke kolom. Pengunaan sistem drop panel ini akan memudahkan pelaksanaan pekerjaan di lapangan, terutama pekerjaan bekisting/ formwork pelat yang mayoritas datar dan tidak ada gangguan balok.

\section{Balok/ beam}

Balok/ beam adalah bagian dari struktural sebuah bangunan yang kaku dan dirancang untuk menanggung dan mentransfer beban menuju elemen-elemen kolom penopang dan sebagai rangka penguat horizontal bangunan. Selain itu ring balok juga berfungsi sebagai pengikat kolom- kolom agar apabila terjadi pergerakan kolomkolom tersebut tetap bersatu padu mempertahankan bentuk dan posisinya semula.

Ring balok dibuat dari bahan yang sama dengan kolomnya sehingga hubungan ring balok dengan kolomnya bersifat kaku dan tidak mudah berubah bentuk. Pola gaya yang tidak seragam dapat mengakibatkan balok melengkung atau defleksi yang harus ditahan oleh kekuatan internal material.

\section{Batasan dimensi balok/ beam untuk pre-elimanary design}

Batasan dimensi balok/ beam pada struktur beton bertulang untuk pre- elimanary design termuat dalam persyaratan- persyaratan umum serta ketentuan teknis perencanaan dan pelaksanaan struktur beton untuk bangunan gedung berdasarkan SNI 2847-2013 pasal 21.5 dan ACI 318-05. Persyaratan beton struktural untuk bangunan gedung sebagai berikut :

1. Gaya tekan aksial terfaktor komponen struktur, $\mathrm{Pu}$, tidak boleh melebihi $0.1 \mathrm{Ag} \mathrm{f}^{\prime} \mathrm{c}$

2. Bentang bersih untuk komponen struktur, ln, tidak boleh kurang dari empat kali tinggi efektifnya.

3. Lebar komponen, bw, tidak boleh kurang dari 0,3h dan tidak boleh lebih kecil dari $250 \mathrm{~mm}$.

4. Tinggi komponen, h, berkisar antara 1/8 - 1/12 dari panjang bentang bersih.

\section{Batasan ukuran tebal slab/ pelat lantai untuk pre-elimanary design}

Batasan dimensi slab/ pelat lantai pada struktur beton bertulang untuk pre- elimanry design termuat dalam persyaratan- persyaratan umum serta ketentuan teknis perencanaan dan pelaksanaan struktur beton untuk bangunan gedung berdasarkan SNI 2847-2013 pasal 9.5.3 dan ACI 318-05. Persyaratan beton struktural untuk bangunan gedung sebagai berikut : 


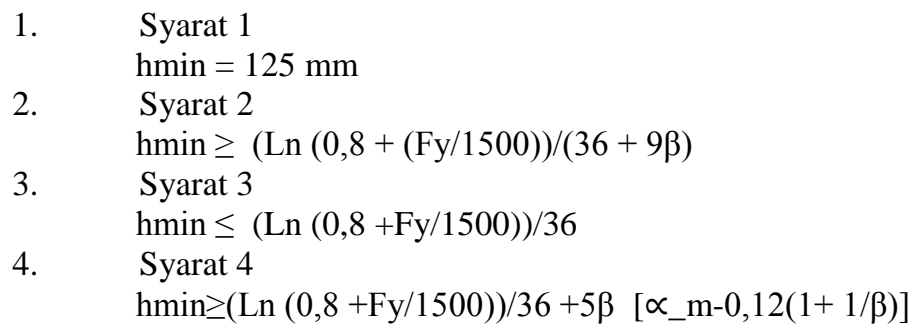

\section{METODOLOGI PENELITIAN}

\section{Pengumpulan data}

Pengumpulan data dilakukan dengan pengamatan di lapangan dan wawancara dengan project manager. Kemudian dilanjutkan dengan menghitung lalu menganalisis data yang didapat sesuai dengan tujuan studi penelitian ini, yakni ingin membandingkan antara 2 jenis pelat lantai, Slab dengan Drop Panels dan Slab dengan Balok. Data- data lapangan yang diperlukan agar tujuan studi penelitian mengenai pekerjaan slab atau pelat lantai bisa terlaksana dengan lancar antara lain :

1. Gambar denah bangunan

2. Luas daerah yang dikerjakan

3. Data mengenai ukuran slab/ pelat lantai, drop panel, dan kolom

4. Data mengenai beban-beban yang bekerja pada slab/ pelat lantai

5. Daftar harga material beton yang digunakan

\section{Perhitungan volume beton untuk tipe slab dengan drop panel}

Setelah melakukan pengumpulan data dengan mengunjungi proyek tempat dilakukannya pekerjaan slab atau pelat lantai yang bersangkutan, maka dilakukan perhitungan volume beton slab, drop panel, dan kolom untuk tipe slab dengan drop panel.

Perhitungan volume beton dapat dilakukan dengan menggunakan rumus berikut:

$$
V=P \times L \times T
$$

Keterangan : V = Volume, $\mathrm{P}=$ Panjang, $\mathrm{L}=$ Lebar, $\mathrm{T}=$ Tinggi.

\section{Perhitungan dimensi balok dan tebal slab}

Perhitungan dimensi balok/ beam dilakukan untuk mendapatkan ukuran balok yang akan digunakan. Perhitungan ini dilakukan karena dalam proyek hanya digunakan komponen drop panel saja (tidak terdapat balok/ beam), sehingga data ukuran balok/ beam belum tersedia.

Untuk mengetahui berapa ukuran balok yang dipakai, maka digunakan rumus berikut:

$$
\begin{aligned}
& h=\frac{1}{10} x L \\
& b=\frac{1}{2} x h
\end{aligned}
$$

Keterangan $: \mathrm{h}=$ Tinggi Balok, $\mathrm{b}=$ Lebar Balok, $\mathrm{L}=$ Panjang Bentang.

Sementara untuk menentukan ketebalan slab, digunakan batasan ukuran tebal slab/ pelat lantai untuk pre-elimanary design seperti yang telah dituliskan di atas.

\section{Pembuatan Desain Jalur Balok}

Setelah menentukan dimensi balok dan tebal slab, maka selanjutnya dilakukan pembuatan gambar desain untuk jalur balok pada struktur tersebut terlebih dahulu. Mendesain jalur balok dilakukan dengan menggunakan gambar denah kerja yang memuat posisi- posisi kolom. ada saat mendesain jalur balok 


\section{Perhitungan volume beton untuk tipe slab dengan balok}

Setelah didapat data mengenai setiap komponen struktur untuk tipe slab dengan balok, maka kemudian dilakukan perhitungan volume beton $s l a b$, balok, dan kolom untuk tipe slab dengan balok. Perhitungan volume beton menggunakan gambar denah kerja dan rumus pada persamaan nomor 1 .

\section{ANALISIS DAN PEMBAHASAN}

Data- data yang telah diperoleh dari hasil pengamatan dan survey di lapangan akan dihitung dengan menggunakan rumus- rumus, kemudian akan dianalisis dan dimasukkan ke dalam tabel yang telah ditabulasikan.

\section{Perhitungan volume beton untuk tipe slab dengan drop panel}

Setelah mendapat data gambar kerja, ukuran, dan spesifikasi dari proyek, maka dilakukan perhitungan volume beton untuk tipe slab dengan drop panel.

\section{Perhitungan volume beton untuk slab}

Berikut adalah denah gambar kerja untuk slab:

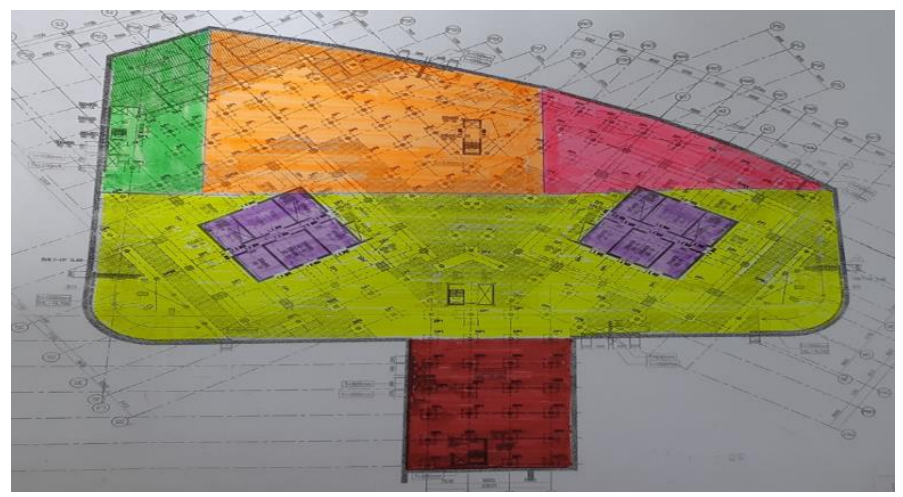

Gambar 1. Gambar denah kerja slab

Luas seluruh permukaan slab adalah:

\begin{tabular}{|c|c|c|c|}
\hline a. & Luas 1 & $=42 \times 31.5$ & $=1323$ \\
\hline b. & Luas 2 & $=148.4 \times 49$ & $=7271.6$ \\
\hline c. & Luas 3 & $=0.5 \times 60.2 \times 38.5$ & $=1158.85$ \\
\hline d. & Luas 4 & $=0.5 \times(38.5+59.5) \times 69.3$ & $=3395.7$ \\
\hline e. & Luas 5 & $=0.5 \times(59.5+46.9) \times 18.9$ & $\begin{array}{l}=1005.48 \\
=14154.63\end{array}$ \\
\hline f. & Luas 6 & $=2 \times(22.4 \times 23.8) \quad$ Hasil Akhir & $\begin{array}{l}=1066.24 \\
=13088.39\end{array}$ \\
\hline
\end{tabular}

Volume total slab dari B1 - B7 untuk tipe slab dengan drop panel adalah
a. $\quad \mathrm{B} 1-\mathrm{B} 4=13088.39 \times 0.22 \times 4$ lantai
$=11517.7832 \quad \mathrm{~m}^{3}$
b. $\mathrm{B} 5-\mathrm{B} 6=13088.39 \times 0.23 \times 2$ lantai
$=6020.6594$
c. $\mathrm{B} 7=14154.63 \times 0.23 \times 1$ lantai
$=3254.8749$
$=20793.3175 \quad \mathrm{~m}^{3}$

\section{Perhitungan volume beton untuk drop panel}

Berikut adalah denah gambar kerja untuk drop panel: 


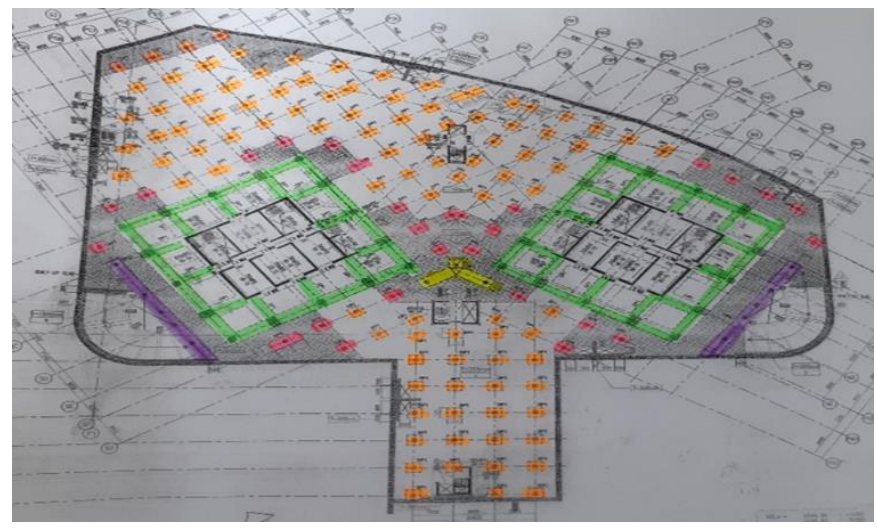

Gambar 2. Gambar denah kerja drop panel

Perhitungan drop panel sebagai berikut:

a. Drop panel DP1

Jumlah $=97$ buah

Volume $=2.8 \times 2.8 \times 0.4 \times 97$ buah $=304.192 \mathrm{~m}^{3}$

b. Drop panel DP5

Jumlah $=27$ buah

Volume $=2.8 \times 2.8 \times 0.42 \times 27$ buah $=95.256 \mathrm{~m}^{3}$

c. Drop panel buruf "Y"

Volume kotak kecil $=2.8 \times 2.8 \times 0.45 \quad=3.528 \mathrm{~m}^{3}$

Volume persegi panjang $=2.8 \times 7.7 \times 0.45 \times 2$ buah $\quad=19.404 \mathrm{~m}^{3}$

Volume segitiga $\quad=0.5 \times 2.8 \times 2.42487 \times 0.45 \quad=1.52767 \mathrm{~m}^{3}$

Volume total $\quad=3.528+19.404+1.52767 \quad=24.45967 \mathrm{~m}^{3}$

d. $\quad$ Drop panel keliling shearwall

Volume arah $\mathrm{x}$ bagian luar $\quad=2.8 \times 89.6 \times 0.45 \times 2 \quad=225.792 \mathrm{~m} 3$

Volume arah y bagian luar $\quad=2.8 \times 77 \times 0.45 \times 2 \quad=194.04 \mathrm{~m} 3$

Volume arah $\mathrm{x}$ bagian dalam $\quad=2.8 \times 37.8 \times 0.4 \times 2 \quad=84.672 \mathrm{~m} 3$

Volume arah y bagian dalam $\quad=2.8 \times 37.8 \times 0.4 \times 2 \quad=84.672 \mathrm{~m} 3$

$\begin{array}{lll}\text { Volume total } & =225.792+194.04+86.672+86.672 & =593.176 \mathrm{~m} 3\end{array}$

e. Drop panel dekat ramp

Volume kiri $=2.8 \times 38.5 \times 0.45 \quad=48.51 \mathrm{~m}^{3}$

Volume kanan $=2.8 \times 35 \times 0.45=44.1 \mathrm{~m}^{3}$

Volume total $=48.51+44.1 \quad=92.61 \mathrm{~m}^{3}$

f. Drop panel persegi panjang

Volume DP1 $=2.8 \times 7 \times 0.4=7.84 \mathrm{~m}^{3}$

Volume DP5 $=2.8 \times 7 \times 0.45=8.82 \mathrm{~m}^{3}$

Volume total $=7.84+8.82=16.66 \mathrm{~m}^{3}$

Jadi volume total penggunaan material beton untuk drop panel adalah

Volume $=($ Jumlah volume total poin a sampai f) $\mathrm{x} 6$ lantai

$=1126.35367 \times 6$

$=6758.12202 \mathrm{~m}^{3}$ 


\section{Perhitungan volume beton untuk kolom}

Berikut adalah denah gambar kerja untuk kolom:

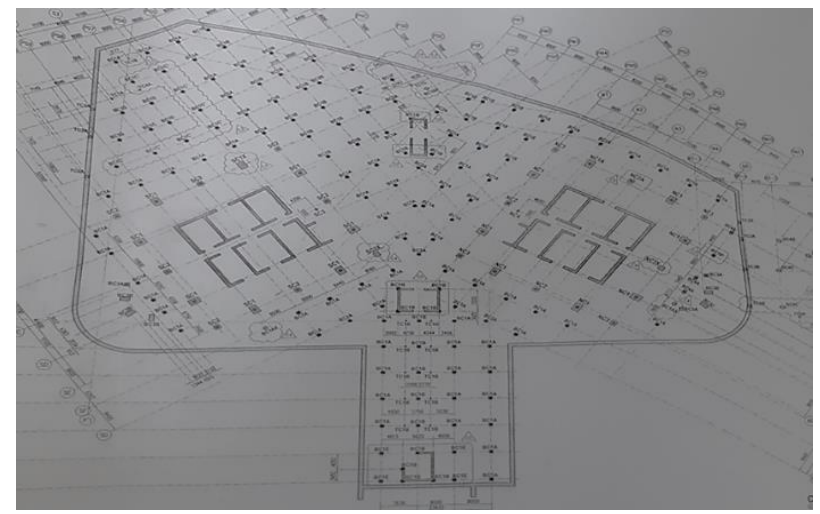

Gambar 3. Gambar denah kerja kolom

Volume kolom adalah :

a. Kolom ukuran $800 \times 800 \mathrm{~mm}$

$$
\text { Jumlah } \quad=141 \text { buah }
$$

Ketinggian $\quad=3.2 \mathrm{~m}$

Volume $\quad=0.8 \times 0.8 \times 3.2 \times 141$

$=288.768 \mathrm{~m}^{3}$

c. Kolom ukuran $1800 \times 2500 \mathrm{~mm}$

$$
\text { Jumlah = } 16 \text { buah }
$$

Ketinggian $\quad=3.2 \mathrm{~m}$

Volume $\quad=1.8 \times 2.5 \times 3.2 \times 16=230.4 \mathrm{~m}^{3}$ b. Kolom ukuran $1400 \times 14000 \mathrm{~mm}$

Jumlah = 16 buah

Ketinggian $\quad=3.2 \mathrm{~m}$

Volume $\quad=1.4 \times 1.4 \times 3.2 \times 16$

$=100.352 \mathrm{~m}^{3}$

Volume total kolom

$$
\begin{aligned}
& =(\text { Jumlah volume total poin a sampai c }) \times 6 \text { lantai } \\
& =(288.768+100.352+230.4) \times 6=3717.12 \mathrm{~m} 3
\end{aligned}
$$

\section{Perhitungan volume beton untuk tipe slab dengan balok}

Karena pada proyek tidak menggunakan konstruksi slab dengan balok. Maka dari itu hal pertama yang dilakukan adalah menentukan dimensi balok dan tebal slab berdasarkan peraturan SNI 2487-2013 dan ACI 318-05. Kemudian langkah berikutnya adalah mendesain jalur balok dari gambar denah proyek yang didapat. Setelah itu barulah selanjutnya akan dihitung jumlah volume penggunaan material beton setiap komponen struktur untuk tipe slab dengan balok. Komponen struktur yang dihitung volumenya yaitu balok, slab, dan kolom. Perhitungan volume dilakukan dengan menggunakan gambar kerja yang diukur skalatis dan menggunakan rumus matematika untuk menghitung volume.

\section{Perhitungan dimensi balok dan tebal slab berdasarkan sni dan aci}

Perhitungan dimensi balok/ beam dan pelat dilakukan dengan membandingkan dari 2 peraturan yang dipakai dalam mendesain struktur tahap awal atau Preliminary Design For Construction. Peraturan yang dipakai untuk dijadikan dasar perhitungan adalah SNI 03-2487-2013 dan ACI 318-05. Hasil perhitungan dengan menggunakan kedua peraturan tersebut akan dibandingkan dan dipilih untuk menentukan dimensi awal balok/ beam

Dimensi Balok

Menentukan tinggi (h) dan lebar (b) balok:

Bentang $8 \mathrm{~m}$

$\mathrm{h}=1 / 10 \mathrm{~L}=800 \mathrm{~mm}$

$\mathrm{b}=1 / 2 \mathrm{~h}=400 \mathrm{~mm}$

\section{Bentang $11 \mathrm{~m}$}

$\mathrm{h}=1 / 10 \mathrm{~L}=1100 \mathrm{~mm}$

$\mathrm{b}=1 / 2 \mathrm{~h}=550 \mathrm{~mm}$ 
Tebal Slab/ Pelat Lantai

$\mathrm{Ln}=8000-(400 / 2)-(400 / 2)=7600 \mathrm{~mm}$

$\beta=1 \mathrm{y} / \mathrm{lx}=8000 / 8000=1<2$, maka pelat 2 arah

fy $=400 \mathrm{MPa}$

$$
\begin{aligned}
\propto & =\frac{\text { I balok }}{\text { I pelat }}=\frac{\frac{1}{12} \times 40 \times 80^{3}}{\frac{1}{12} \times 760 \times 20^{3}} \\
& =3.368
\end{aligned}
$$

Keterangan : Ln : bentang bersih pelat

$\beta \quad$ : perbandingan bentang panjang dan bentang pendek pelat

fy : mutu tulangan baja

$\alpha \quad$ : perbandingan inersia balok dan inersia pelat

Asumsi digunakan pelat dengan ketebalan $200 \mathrm{~mm}$,

Cek syarat:

$$
\begin{array}{ll}
\text { 1. } & \text { hmin } \geq 125 \mathrm{~mm} \\
& 200 \mathrm{~mm} \geq 125 \mathrm{~mm}(\mathrm{OK}) \\
\text { 2. } & \text { hmin } \geq \operatorname{Ln} \frac{0.8+\frac{\mathrm{fy}}{1500}}{36+9 \beta} \\
& 200 \mathrm{~mm} \geq 180.15 \mathrm{~mm}(\mathrm{OK})
\end{array}
$$

3. $\quad \operatorname{hmin} \leq \operatorname{Ln} \frac{0.8+\frac{\mathrm{fy}}{1500}}{36}$

$200 \mathrm{~mm} \leq 225.185 \mathrm{~mm}(\mathrm{OK})$

4. $\quad h m i n \geq \operatorname{Ln} \frac{0.8+\frac{\mathrm{fy}}{1500}}{36+5 \beta\left(\alpha-0.12\left(1+\frac{1}{\beta}\right)\right)}$

$200 \mathrm{~mm} \geq 156.984 \mathrm{~mm}(\mathrm{OK})$

Maka untuk itu digunakan slab/ pelat lantai dengan ketebalan $200 \mathrm{~mm}$.

\section{Mendesain jalur balok}

Setelah menentukan dimensi balok dan tebal slab, maka selanjutnya dilakukan pembuatan gambar desain untuk jalur balok pada struktur tersebut terlebih dahulu. Mendesain jalur balok dilakukan dengan menggunakan gambar denah kerja yang memuat posisi- posisi kolom. Dalam mendesain jalur balok, hal yang harus diperhatikan adalah setiap balok harus bertumpu pada salah satu kolom dan balok harus saling berhubungan satu dengan yang lainnya. Hal ini bertujuan supaya balok- balok dapat saling memegang satu sama lain dan dapat menahan beban bersama- sama.

\section{Perhitungan volume beton untuk slab}

Dengan gambar dan luasan yang sama seperti di atas, maka dapat dihitung volume slab untuk tipe slab dengan balok adalah

Volume total slab dari B1 - B7 untuk tipe pelat slab dengan balok adalah

$$
\begin{aligned}
\text { a. } \quad \mathrm{B} 1-\mathrm{B} 6=13088.39 \times 0.2 \times 6 \text { lantai } & =15706.068 & \mathrm{~m}^{3} \\
\text { b. } \mathrm{B} 7 \quad=14154.63 \times 0.2 \times 1 \text { lantai } & =2830.926 & \mathrm{~m}^{3} \\
\text { Total } & =18.536 .994 & \mathrm{~m}^{3}
\end{aligned}
$$

\section{Perhitungan volume beton untuk balok}

Dengan menggunakan gambar desain jalur balok, maka dapat dihitung volume beton untuk balok.

Volume balok adalah :
a. Balok ukuran $800 \times 400 \mathrm{~mm}$
Panjang bentang $=2243.5 \mathrm{~m}$
Volume $=0.4 \times 0.8 \times 2243.5=717.92 \mathrm{~m}^{3}$
b. Balok ukuran $1100 \times 550 \mathrm{~mm}$
Panjang bentang $=739.2 \mathrm{~m}$
Volume $=1.1 \times 0.55 \times 739.2=447.216 \mathrm{~m}^{3}$

Volume total balok $=(717.92+447.216) \times 6$ lantai $=6990.816 \mathrm{~m}^{3}$

\section{Perhitungan volume beton untuk kolom}

Perhitungan volume kolom untuk tipe slab dengan balok sama dengan perhitungan volume kolom untuk tipe slab dengan drop panel. 


\section{Perhitungan total keseluruhan volume material beton}

Setelah dilakukan perhitungan volume setiap komponen struktur, maka didapat total keseluruhan volume material beton yang digunakan. Total keseluruhan volume material beton yang digunakan ditabulasikan pada tabel di bawah ini:

Tabel 1. Tabulasi volume pemakaian material beton

\begin{tabular}{cccccc}
\hline Jenis Slab & $\begin{array}{c}\text { Slab } \\
\left(\mathrm{m}^{3}\right)\end{array}$ & $\begin{array}{c}\text { Drop Panel } \\
\left(\mathrm{m}^{3}\right)\end{array}$ & $\begin{array}{c}\text { Kolom } \\
\left(\mathrm{m}^{3}\right)\end{array}$ & $\begin{array}{c}\text { Balok } \\
\left(\mathrm{m}^{3}\right)\end{array}$ & $\begin{array}{c}\text { Total } \\
\left(\mathrm{m}^{3}\right)\end{array}$ \\
\hline $\begin{array}{c}\text { Slab dengan } \\
\text { Drop Panel }\end{array}$ & 20793.3175 & 6758.12202 & 3717.12 & Tidak ada & 31268.55952 \\
\hline $\begin{array}{c}\text { Slab dengan } \\
\text { Balok }\end{array}$ & 18536.994 & Tidak ada & 3717.12 & 6990.816 & 29244.93 \\
\hline
\end{tabular}

\section{Perhitungan volume material beton tiap lantai}

Dari hasil perhitungan volume setiap komponen struktur, maka akan dihitung banyaknya volume material beton yang digunakan untuk tiap lantai. Setelah itu akan dibandingkan berapa persen perbedaan volume beton tiap lantai antara kedua tipe pelat lantai tersebut. Perhitungan volume material beton yang digunakan tiap lantai ditabulasikan pada tabel di bawah ini:

Tabel 2. Tabel persentase perbedaan volume material beton per lantai

\begin{tabular}{|c|c|c|c|}
\hline Lantai & Tipe Pelat Lantai & Total Volume Beton $\left(\mathrm{m}^{3}\right)$ & Perbedaan $(\%)$ \\
\hline \multirow[t]{2}{*}{ B1 } & Slab Dengan Drop Panel & 4625.31947 & $4.821 \%$ \\
\hline & Slab Dengan Balok & 4402.334 & \\
\hline \multirow[t]{2}{*}{$\mathrm{B} 2$} & Slab Dengan Drop Panel & 4625.31947 & $4.821 \%$ \\
\hline & Slab Dengan Balok & 4402.334 & \\
\hline \multirow[t]{2}{*}{ B3 } & Slab Dengan Drop Panel & 4625.31947 & $4.821 \%$ \\
\hline & Slab Dengan Balok & 4402.334 & \\
\hline \multirow[t]{2}{*}{ B4 } & Slab Dengan Drop Panel & 4625.31947 & $4.821 \%$ \\
\hline & Slab Dengan Balok & 4402.334 & \\
\hline \multirow[t]{2}{*}{ B5 } & Slab Dengan Drop Panel & 4756.20337 & $7.440 \%$ \\
\hline & Slab Dengan Balok & 4402.334 & \\
\hline \multirow[t]{2}{*}{ B6 } & Slab Dengan Drop Panel & 4756.20337 & $7.440 \%$ \\
\hline & Slab Dengan Balok & 4402.334 & \\
\hline \multirow[t]{2}{*}{ B7 } & Slab Dengan Drop Panel & 3254.8749 & $13.025 \%$ \\
\hline & Slab Dengan Balok & 2830.926 & \\
\hline
\end{tabular}




\section{Perhitungan tambahan biaya (slab dengan balok)}

Bila menggunakan sistem konstruksi pelat lantai tipe slab dengan balok, maka penggunaan material beton memang akan lebih hemat/ lebih sedikit. Akan tetapi di sisi lain juga akan mengakibatkan penambahan volume pekerjaan dan penambahan biaya untuk beberapa pekerjaan lainnya. Misalnya seperti biaya untuk penggalian yang bertambah Rp. 4.140.229.275,-, , biaya pembuatan retainning wall yang bertambah Rp. 2.052.960.000,-, dan biaya untuk pekerjaan dewatering.

\section{Analisis dan pembahasan}

Dari hasil perhitungan, volume beton yang diperlukan untuk sistem konstruksi tipe slab dengan balok lebih sedikit daripada sistem konstruksi tipe slab dengan drop panel. Dengan perbedaan jumlah volume beton sebesar 2023.63 $\mathrm{m}^{3}$ tersebut, maka dapat dihitung selisih biaya yang dikeluarkan oleh proyek. Berdasarkan harga pasar ready mix beton f'c $50 \mathrm{MPa}$, yaitu Rp. 940.000,- maka selisih biaya yang dapat dihemat oleh proyek sebesar Rp. 1.902.211.749,-. Tetapi angka selisih biaya tersebut tidak menjadikan tipe slab dengan balok lebih dipilih, karena di sisi lain bila digunakan tipe slab dengan balok ada beberapa pekerjaan yang justru menyebabkan biayanya menjadi membengkak, seperti pekerjaan galian tanah, pembuatan retaining wall, dll. Bila semua biaya tersebut dijumlahkan maka didapatkan total pembengkakan biaya sebesar Rp. 6.193.189.275,-. Dan perlu diingat penambahan biaya tersebut masih akan bertambah bila biaya seperti untuk pembesian retaining wall dan biaya dewatering ikut diperhitungkan.

Berikut ini adalah tabel penambahan biaya apabila menggunakan sistem pelat lantai tipe slab dengan balok.

Tabel 3. Tabel penambahan biaya bila menggunakan slab dengan balok

\begin{tabular}{ccc}
\hline Jenis Pekerjaan & Biaya & Pengaruh Terhadap Biaya Total \\
\hline Volume Beton & + Rp. 1.902.211.749,- & Penghematan Biaya \\
\hline Galian Tanah & - Rp. 4.140.229.275,- & Penambahan Biaya \\
\hline Retainning Wall & - Rp. 2.052.960.000,- & Penambahan Biaya \\
\hline Total & - Rp. 4.290.977.526,- & Penambahan Biaya \\
\hline
\end{tabular}

\section{Alasan digunakan pelat tipe slab dengan drop panel}

Dari analisis di atas, diketahui bahwa bila menggunakan tipe slab dengan balok memang lebih hemat dari sisi penggunaan material beton daripada tipe slab dengan drop panel. Namun ternyata ada beberapa pekerjaan yang biayanya justru membengkak. Hal inilah yang menjadi fokus pertimbangan konsultan perencana lebih memilih menggunakan slab dengan drop panel daripada slab dengan balok. Karena bila dihitung dari sisi value for money, slab dengan drop panel lebih unggul dibanding slab dengan balok.

Nilai value for money ini terlihat jelas pada saat jumlah pembengkakan biaya yang dikeluarkan ternyata lebih besar daripada jumlah biaya yang dihemat bila menggunakan slab dengan balok. Selain itu, di sisi lain pengerjaan slab dengan drop panel cenderung lebih cepat dan mudah daripada pelat dengan balok. Karena dalam pengerjaannya, slab dengan drop panel tidak memerlukan bekisting yang rumit, sehingga dapat mempermudah dan mempercepat waktu pengerjaan. Walaupun memang untuk saat ini sumber daya manusia yang bisa mengerjakan pelat tipe slab dengan drop panel di Indonesia masih jarang dan sedikit. 


\section{KESIMPULAN}

1. Jumlah volume beton yang diperlukan untuk tipe slab dengan drop panel diperoleh sebanyak $31268.55952 \mathrm{~m}^{3}$. Sedangkan jumlah volume beton yang diperlukan tipe slab dengan balok diperoleh sebanyak $29244.93 \mathrm{~m}^{3}$. Artinya, jumlah volume beton yang diperlukan tipe slab dengan drop panel lebih banyak 6,47\% daripada tipe slab dengan balok.

2. Perbedaan selisih volume beton antara tipe slab dengan drop panel dan slab dengan balok tiap lantai yaitu:

Tabel 4. Tabel perbedaan volume beton per lantai

\begin{tabular}{cc}
\hline Level Lantai & Perbedaan Volume Beton \\
\hline B1-B4 & $4.821 \%$ \\
\hline B5 - B6 & $7.440 \%$ \\
\hline B7 & $13.025 \%$. \\
\hline
\end{tabular}

3. Bila menggunakan tipe slab dengan balok maka akan ada penambahan biaya sebesar $14.60 \%$ dari total biaya jika menggunakan tipe slab dengan drop panel.

4. Bila menggunakan tipe slab dengan balok maka kedalaman galian tanah bertambah sekitar $3.9 \mathrm{~m}$.

\section{DAFTAR PUSTAKA}

ACI Committee. (2015). Building Code Requirements for Structural Concrete ACI 318-14, American Concrete Institute.

Badan Standardisasi Nasional. (2013). SNI 2847-2013: Persyaratan Beton Struktural Untuk Bangunan Gedung. Jakarta.

Chavan, G. R. dan Tande, S. N. (2016). "Analysis and Design of Flat Slab. International Journal of Latest Trends in Engineering and Technology."

Daniel R. dan Stanley P. (2017) "Jurnal Studi Perbandingan Penggunaan Flat Plate Dan Flat Slab Dengan Drop Panel."

Teruna, D. R. dan Prawira, S. (2017) “Studi Perbandingan Penggunaan Flat Plate Dan Flat Slab Dengan Drop Panel Pada Struktur Bangunan Ditinjau Dari Segi Volume”. Universitas Sumatera Utara. Medan.

Detik.com. (2018). Pasar Konstruksi Republik Indonesia di https://finance.detik.com/infrastruktur/d3815604/pengusaha-pasar-konstruksi-ri-diproyeksi-capai-rp-451-t-di-2018 (diakses 25 September 2018). 